\title{
Calorie and protein delivery in critically ill surgical and non-surgical patients receiving enteral nutrition therapy
}

\section{Aporte de calorías y proteínas a pacientes quirúrgicos y no quirúrgicos en estado crítico, que reciben nutrición enteral}

\begin{abstract}
Providing enteral nutritional therapy to critically ill patients is a challenge, especially during the first days after starting intensive care. These challenges appear to be greater in critically ill surgical patients. Objectives: Describe and compare enteral nutrition practices in critically ill surgical and non-surgical patients. Methods: We conducted a prospective cohort study of surgical and non-surgical patients receiving exclusive enteral nutritional therapy. The values for calorie and protein delivery during the first week after admission to the intensive care unit were recorded. Results: 103 patients were enrolled (54.4\% male, mean age: 63.9 years, $26.2 \%$ surgical). The median time of initiation of enteral nutritional therapy was the third day in non-surgical and the fourth day in surgical patients. Surgical patients had a lower calorie and protein delivery than non-surgical patients on the second to fourth days after admission. At the end of the first week, $20.2 \%$ of the patients had not received any diet, and there was no significant difference in nutrient delivery between the groups. Of the surgical and non-surgical patients, $42.9 \%$ and $39.3 \%$ were receiving $\geq 20$ $\mathrm{kcal} / \mathrm{kg} / \mathrm{day}$, and $28.6 \%$ and $34.4 \%$ were receiving $\geq 1.2 \mathrm{~g} /$ $\mathrm{kg}$ of protein per day, respectively. Conclusion: There was a delay in starting patients on enteral nutritional therapy and calorie and protein delivery was low, especially among surgical patients. By the end of the first week, calorie and protein delivery was similar in both groups.

Keywords: Energy needs; Enteral nutrition; Intensive care; Protein need; Surgical procedures.
\end{abstract}

\section{RESUMEN}

Proporcionar terapia nutricional enteral a pacientes críticos es un desafío, especialmente durante los primeros días después de comenzar los cuidados intensivos. Estos desafíos parecen ser mayores en pacientes quirúrgicos críticos. El propósito del estudio fue describir y comparar las prácticas de nutrición enteral en pacientes críticos quirúrgicos y no quirúrgicos. Se realizó un estudio de cohorte prospectivo de pacientes quirúrgicos y no quirúrgicos que recibieron terapia nutricional enteral exclusiva. Se registraron los datos de entrega de calorías y proteínas durante la primera

\begin{abstract}
Clarissa Simon Factum", Túlio Henrique de Souza Moreira², Camila Dias Nascimento Rocha ${ }^{3}$, Marcelle Ferreira Saldanha ${ }^{4}$, Flávia Moraes Silva ${ }^{5}$, Ann Kristine Jansen ${ }^{6, *}$.
\end{abstract}

1. Hospital Risoleta Tolentino Neves, Belo Horizonte, Brazil. 2. Nutrition Course, Universidade Federal de Minas Gerais, Belo Horizonte, Brazil. 3. Postgraduate Course in Nutrition and Health, Universidade Federal de Minas Gerais, Belo Horizonte, Brazil. 4. Municipal Health Secretariat, Belo Horizonte, Brazil. 5. Department of Nutrition, Universidade Federal de Ciências da Saúde, Porto Alegre, Brazil

6. Department of Nutrition, Universidade Federal de Minas Gerais, Belo Horizonte, Brazil.

*Corresponding Author: Ann Kristine Jansen, Department of Nutrition, Universidade Federal de Minas Gerais, Avenida Prof. Alfredo Balena, 190, Escola de Enfermagem, CEP 30130-100, Brazil. E-mail: annkjansen@gmail.com

Este trabajo fue recibido el 26 de febrero de 2020. Aceptado con modificaciones: 05 de julio de 2020. Aceptado para ser publicado: 31 de julio de 2020.

semana después de la admisión a la unidad de cuidados intensivos. Se estudiaron 103 pacientes $(54,4 \%$ hombres, edad media: 63,9 años, 26,2\% quirúrgicos). La mediana de tiempo de inicio de la terapia nutricional enteral fue el tercer día en pacientes no quirúrgicos y el cuarto día en pacientes quirúrgicos. Los pacientes quirúrgicos tuvieron una entrega de calorías y proteínas más baja que los pacientes no quirúrgicos en el segundo a cuarto día después del ingreso. Al final de la primera semana, el 20,2\% de los pacientes no habían recibido ningún aporte nutricional, y no hubo diferencias significativas en el suministro de nutrientes entre los grupos. De los pacientes quirúrgicos y no quirúrgicos, $42,9 \%$ y $39,3 \%$ estaban recibiendo $\geq 20 \mathrm{kcal} / \mathrm{kg} / \mathrm{día}$, y $28,6 \%$ y $34,4 \%$ estaban recibiendo $\geq 1,2 \mathrm{~g} / \mathrm{kg}$ de proteína 
por día, respectivamente. Conclusiones: Hubo un retraso en el inicio de los pacientes en terapia nutricional enteral y la entrega de calorías y proteínas fue baja, especialmente entre los pacientes quirúrgicos. Al final de la primera semana, la entrega de calorías y proteínas fue similar en ambos grupos. Palabras clave: Cuidados intensivos; Necesidad de proteínas; Necesidades energéticas; Nutrición enteral; Procedimientos quirúrgicos.

\section{INTRODUCTION}

Enteral nutritional therapy (ENT) in intensive care is administered to maintain gastrointestinal integrity, reduce the risk of systemic infections, alleviate the severity of the disease, and modulate stress and the immune response ${ }^{1}$, and its success depends on strictly following nutritional therapy protocols ${ }^{2}$. To avoid the overfeeding and refeeding syndrome, the most recent protocol on ENT for critically ill patients recommends the treatment to start within the first 48 hours after hospitalization, with energy intake not to exceed $70 \%$ of the caloric needs and protein not to exceed $1.3 \mathrm{~g} / \mathrm{kg} /$ day in the first 3 days $^{3}$. However, there are often gaps between these nutritional recommendations and the real calorie and protein delivery in critically ill patients. Often, nutritional requirements, especially the protein requirements, are not met during the first few days of hospitalization ${ }^{4,5,6,7}$.

Provision of exogenous protein is essential for patients in a catabolic state to reduce nitrogen loss and optimize the synthesis of positive acute-phase proteins ${ }^{8}$. Studies have shown that protein delivery improves clinical outcomes $^{9,10,11}$, muscle mass ${ }^{12}$, and plasma amino acid level $\mathrm{s}^{13}$ in critical patients, whereas calorie delivery does not always improve prognosis ${ }^{9,14,15}$, especially if there is overfeeding ${ }^{9}$.

An observational study of patients on mechanical ventilation and no sepsis assessed the relationship between the adequacy of nutritional therapy and outcomes, revealed that providing patients with $95 \%$ of their calorie requirements, as determined by indirect calorimetry, during the first four days was associated with a higher mortality rate $^{9}$. A trial of different levels of calorie intake during the first week after admission to the intensive care unit (ICU) found that the hypocaloric group who received $50 \%$ of their calorie needs, had a lower insulin demand and less gastrointestinal intolerance, but a higher incidence of nosocomial infections than the group who received $100 \%$ of their calorie needs. There was no difference in in-hospital mortality ${ }^{14}$. A meta-analysis of studies using indirect calorimetry to determine the calorie requirements of critically ill patients found a trend, where hypocaloric diets were associated with higher short-term mortality, with no significant differences in long-term mortality, incidence of infection, or length of stay in the $\mathrm{ICU}^{3}$. Another study found no difference in dietary tolerance, incidence of diarrhea and nosocomial infection, length of ICU and hospital stay, and mortality between patients who received 70 to 100 percent of their caloric needs to those who were administered 40 to 60 percent of their calorie needs. Both groups received the same amount of protein ${ }^{15}$. According to Hoffer et $\mathrm{al}^{8}$, short-term calorie deficiency is rarely a problem in critically ill patients, despite the increase in energy needs, due to the energy reserves found in adipose tissue that many patients have. However, protein stores are more restricted to and are rapidly catabolized in critical illness. Thus, the supply of proteins becomes crucial, even in the presence of caloric restriction ${ }^{8}$.

The differences between recommendations, prescription, and actual delivery of calories and protein, tends to be greater in critically ill surgical patients. Reportedly, critically ill surgical patients start ENT significantly later than critically ill non-surgical patients, with the former receiving fewer calories and nutrients ${ }^{16}$. Surgical patients experience more frequent gastrointestinal side effects, such as vomiting, even with the use of prophylactic prokinatic agents. Surgical patients also have more hemodynamic instability and an increased possibility of further surgical intervention, all of which can lead to delayed introduction of ENT in these patients ${ }^{16,17}$.

The aim of this study is to describe and compare ENT practices during the first week of hospitalization, and outcomes in critically ill surgical and non-surgical patients, after admission to the ICU.

\section{MATERIAL AND METHODS}

We conducted a prospective cohort study of patients admitted to an ICU in a public hospital in Brazil, between May and October 2017.

The study was approved by the Research Ethics Committees of the Federal University of Minas Gerais, Brazil (reference numbers: 63688016.8.0000.5149) and was conducted in accordance with their ethical standards and the Declaration of Helsinki. All participants or a relative provided written informed consent after the nature of the procedures had been explained to them, in accordance with the ethical standards of the responsible committee on human experimentation.

\section{Participants}

For the patients to be included in this study, they had to be $\geq 18$ years of age, screened for nutritional risk within 48 hours of admission to the ICU, put on exclusive ENT, had records of daily ENT intake during the first week of hospitalization, and had directly or indirectly provided written informed consent to participate in the study. Patients were excluded if they were pregnant, had childbirth complications, were brain dead, in palliative care, or on oral, parenteral, or mixed nutritional therapy. All patients received ENT in a closed system with infusion for 22 hours per day.

We calculated the sample size based on the calorie adequacy of $49.6 \pm 30.2 \%$ in critically ill clinical patients 
and $33.4 \pm 29.5 \%$ in critically ill surgical patients, as reported by Drover et $\mathrm{al}^{16}$, with a confidence interval of $90 \%$, a ratio of non-surgical to surgical patients of 3:1 and $20 \%$ attrition. The required sample size was calculated using an online calculator (https://www.openepi.com/ SampleSize/SSMean.htm) and was estimated to be 101 patients, with 25 surgical and 76 non-surgical critically ill patients. Patients were assigned to the surgical or non-surgical group according to the recorded cause of admission to the ICU. It is important to highlight that the difference in protein adequacy between surgical and non-surgical patients $(50.4 \%$ versus $33.6 \%)$ in the cited study was similar to calorie adequacy. Thus, the calculated sample size would remain the same, even if protein adequacy had been considered ${ }^{16}$.

\section{Data collection}

Demographic and clinical data at the time of ICU admission were collected from the patient's medical records. These included: age, sex, Acute Physiologic and Chronic Health Disease (APACHE), Sepsis-related Organ Failure Assessment (SOFA), administration of mechanical ventilation, fasting blood glucose, blood lactate, and use of vasoactive amines. During the first week after ICU admission, gastrointestinal complications were monitored. Data on the number of calories and the amount of proteins prescribed per day, as calculated by the consulting nutritionists, were collected from the medical records. Length of stay in the ICU and the hospital was also extracted from the medical records. Information on the outcomes for the patients, either discharged home or death, were also collected.

Nutritional risk was assessed using the modified Nutrition Risk in the Critically ill (NUTRIC) Score. Patients with a score $\geq 5$ were classified as having high nutritional risk, while those with a score $<5$ were classified as having low nutritional risk ${ }^{18}$.

Nutritional status was evaluated using the Subjective Global Assessment (SGA), and patients were classified as well nourished (SGA-A), moderately malnourished $(\mathrm{SGA}-\mathrm{B})$ or severely malnourished $(\mathrm{SGA}-\mathrm{C})^{19}$. The SGA was assessed when the patient was lucid and able to provide a detailed nutritional history. Alternatively, the SGA was assessed by interviewing an appropriate informant in patients who were on mechanical ventilation, under sedation, or had any other condition that prevented them from responding.

The number of calories and the amount of protein delivered daily during the first week were calculated based on the records of 24-hour enteral infusion volumes completed by the nursing staff.

The adequacy of calorie and protein provision to study participants was evaluated based on the recommended minimum calorie intake of $20 \mathrm{Kcal} / \mathrm{kg} / \mathrm{day}^{2}$ and protein intake of $1.2 \mathrm{~g} / \mathrm{kg} / \mathrm{day}^{1}$ for critically ill patients in the first week of hospitalization.

\section{Statistical analysis}

Statistical analysis was performed using SPSS, Version 17 (SPSS Inc, Chicago, IL, USA). Statistical significance was defined as $\mathrm{P}<0.05$. The Shapiro-Wilk test was used to evaluate the distribution of the quantitative variables, which were expressed as means and standard deviations if the values were normally distributed, and as medians and 25th and 75th percentile values if they were not. Categorical variables were expressed as frequencies and proportions.

Participants were categorized as surgical if they were post-operative, or as non-surgical if they were admitted to the ICU for any other reason. The values of the independent quantitative variables of the surgical and non-surgical groups were compared using the Student's t-test for independent samples if they were normally distributed, or by using the Mann-Whitney $U$ test if they were not. Depending on the expected frequencies of the categorical variables in each group, these were compared using Pearson's chi-square test or the likelihood-ratio test as appropriate.

\section{RESULTS}

A total of 103 patients took part in the study, of which $27(26.2 \%)$ patients were post-operative. The participant characteristics are shown in table 1. Some significant differences were observed between groups at baseline, including that surgical patients were younger and had a lower nutritional risk.

Patients' calorie and protein intake and gastrointestinal complications during the first week of ICU admission and their surgical status are presented in table 2. Surgical patients started ENT a day later than non-surgical patients, and their median calorie and protein intake were markedly lower. At the end of the first week, 20.2\% remained without any type of nutritional therapy. There was no significant difference between groups in the occurrence of gastrointestinal disorders.

The daily calorie and protein intake per kg body weight through ENT during the patients' first week in the ICU are shown in figure 1 . Surgical patients had a significantly lower calorie (1A) and protein (1B) delivery than non-surgical patients on the second to fourth days after ICU admission.

Figure 2 shows the proportion of patients who had a calorie delivery $\geq 20 \mathrm{kcal} / \mathrm{kg} /$ day $(2 \mathrm{~A})$ and protein delivery $\geq 1.2 \mathrm{~g} / \mathrm{kg} / \mathrm{day}$ (2B) during the first week after ICU admission. At the end of the first week, $42.9 \%$ of the surgical and $39.3 \%$ of the non-surgical patients were receiving $\geq 20 \mathrm{kcal} /$ $\mathrm{kg} / \mathrm{day}$, while $28.6 \%$ of the former group and $34.4 \%$ of the latter group were receiving $\geq 1.2 \mathrm{~g} / \mathrm{kg}$ of protein per day, without a significant difference between groups $(P>0.05)$.

The hospital outcomes according to surgical status are shown in table 3 . Mortality was significantly lower $(P=0.037)$ and the instances of home discharge were significantly higher $(P=0.010)$ among surgical patients than non-surgical patients. 
Table 1. Participant characteristics on admission according to surgical status.

\begin{tabular}{|c|c|c|c|c|}
\hline Characteristic & $\begin{array}{c}\text { Total } \\
n=103\end{array}$ & $\begin{array}{c}\text { Surgical } \\
n=27\end{array}$ & $\begin{array}{c}\text { Non-surgical } \\
n=76\end{array}$ & P-value \\
\hline Male, n (\%) & $56(54.4)$ & $18(66.7)$ & $35(46.1)$ & $0.066^{*}$ \\
\hline Age (years), mean (SD) & $63.9(16.7)$ & $57.3(20.7)$ & $66.3(14.4)$ & $0.044^{+}$ \\
\hline Mechanical ventilation, n (\%) & $91(88.3)$ & $25(92.6)$ & $66(86.8)$ & $0.404^{*}$ \\
\hline SOFA, mean (SD) & $8.4(3.6)$ & $7.9(4.0)$ & $8.6(3.5)$ & $0.425^{+}$ \\
\hline High nutritional risk, n (\%) & $79(78.2)$ & $17(63.0)$ & $62(81.6)$ & $0.025^{*}$ \\
\hline Nutritional Status (SGA), n (\%) & & & & $0.183^{*}$ \\
\hline Moderately malnourished & $35(34.0)$ & $10(37.0)$ & $25(32.9)$ & \\
\hline Severely malnourished & $5(4.8)$ & $0(0.0)$ & $5(6.6)$ & \\
\hline Use of vasoactive amines, n (\%) & $38(36.9)$ & $10(37.0)$ & $28(36.8)$ & $0.986^{*}$ \\
\hline
\end{tabular}

${ }^{*}$ Chi-square test, ${ }^{+}$Student's t-test, ${ }^{\ddagger}$ Mann-Whitney U test. Abbreviations: APACHE, Acute Physiologic and Chronic Health Disease; P25-P75, 25th and 75th percentile values; SD, standard deviation; SGA, Subjective Global Assessment; SOFA, Sepsis-related Organ Failure Assessment.

Table 2. Enteral nutritional therapy and gastrointestinal complications during the first week after admission to the intensive care unit, according to surgical status.

\begin{tabular}{|c|c|c|c|c|}
\hline Characteristics & $\begin{array}{c}\text { Total } \\
n=103\end{array}$ & $\begin{array}{c}\text { Surgical } \\
n=27\end{array}$ & $\begin{array}{l}\text { Non-surgical } \\
\qquad n=76\end{array}$ & P-value \\
\hline Day of starting ENT, median (P25-P75) & $\begin{array}{c}3.0 \\
(2.0-4.0)\end{array}$ & $\begin{array}{c}4.0 \\
(3.0-5.0)\end{array}$ & $\begin{array}{c}3.0 \\
(2.0-4.0)\end{array}$ & $0.015 \neq$ \\
\hline \multicolumn{5}{|l|}{ Fasting, n (\%) } \\
\hline Day 1 & $89(86.4)$ & $26(96.3)$ & $63(82.9)$ & $0.081^{*}$ \\
\hline Day 2 & $69(67.0)$ & $24(88.9)$ & $45(59.2)$ & $0.005 *$ \\
\hline Day 3 & $42(42.9)$ & $16(59.3)$ & $26(34.2)$ & $0.025^{*}$ \\
\hline Day 4 & $32(32.7)$ & $14(51.8)$ & $18(23.7)$ & $0.007^{*}$ \\
\hline Day 5 & $28(29.8)$ & $11(40.7)$ & $17(22.4)$ & $0.046 *$ \\
\hline Day 6 & $23(26.7)$ & $6(22.2)$ & $17(22.4)$ & $0.828^{*}$ \\
\hline Day 7 & $17(20.2)$ & $5(18.5)$ & $12(15.8)$ & $0.615^{*}$ \\
\hline \multicolumn{5}{|c|}{ Delivery of calories in the first week (kcal/day), median (P25-P75) } \\
\hline & $\begin{array}{c}573.6 \\
(123.4-967.4)\end{array}$ & $\begin{array}{c}196.0 \\
(0.0-794.0)\end{array}$ & $\begin{array}{c}626.3 \\
(269.1-986.6)\end{array}$ & $0.022^{\ddagger}$ \\
\hline \multicolumn{5}{|c|}{ Delivery of protein in the first week (g/day), median (P25-P75) } \\
\hline & $\begin{array}{c}29.8 \\
(6.8-51.7)\end{array}$ & $\begin{array}{c}8.0 \\
(0.0-39.0)\end{array}$ & $\begin{array}{c}32.0 \\
(13.0-54.0)\end{array}$ & $0.028^{\ddagger}$ \\
\hline \multicolumn{5}{|l|}{ Gastrointestinal disorders, $\mathrm{n}(\%)$} \\
\hline Vomiting & $2(1.9)$ & $1(3.7)$ & $1(1.3)$ & $0.440^{*}$ \\
\hline Diarrhea & $21(20.4)$ & $3(11.1)$ & $18(23.7)$ & $0.164^{*}$ \\
\hline Gastric stasis & $24(23.3)$ & $9(33.3)$ & $15(19.7)$ & $0.151^{*}$ \\
\hline
\end{tabular}

${ }^{\ddagger}$ Mann-Whitney U test, ${ }^{*}$ Chi-square test. Abbreviations: ENT, Enteral nutrition therapy; P25-P75, 25th and 75th percentile values. 


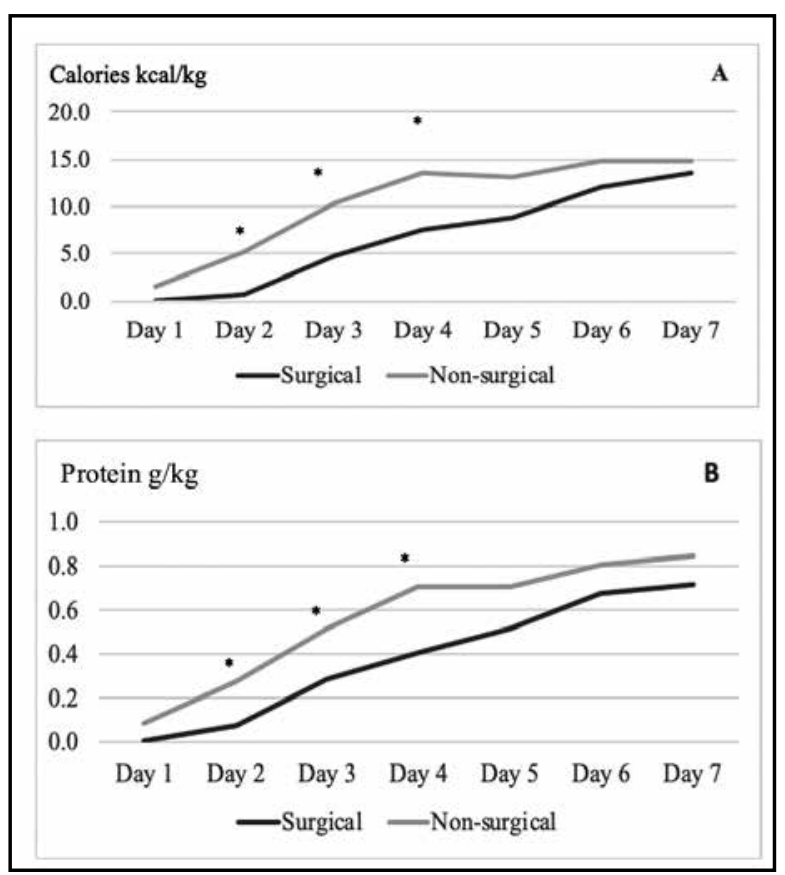

Figure 1: Mean calories per kilogram of body weight (kcal/ $\mathrm{kg}$ ) per day (A) and proteins in grams per kilogram of body weight (protein $(\mathrm{g}) / \mathrm{kg}$ ) per day (B) infused by the enteral route during the first week after admission to the intensive care unit. Surgical patients had a significantly lower mean calorie intake than non-surgical patients on the second $(\mathrm{P}=0.003)$, third $(\mathrm{P}=$ $0.015)$, and fourth $(\mathrm{P}=0.010)$ days after admission. They also had a significantly lower mean protein intake than non-surgical patients on the second $(\mathrm{P}=0.006)$; third $(\mathrm{P}=0.019)$; and fourth $(\mathrm{P}=0.016)$ days after admission. Mann-Whitney $\mathrm{U}$ test. ${ }^{*} \mathrm{P}<0.05$.

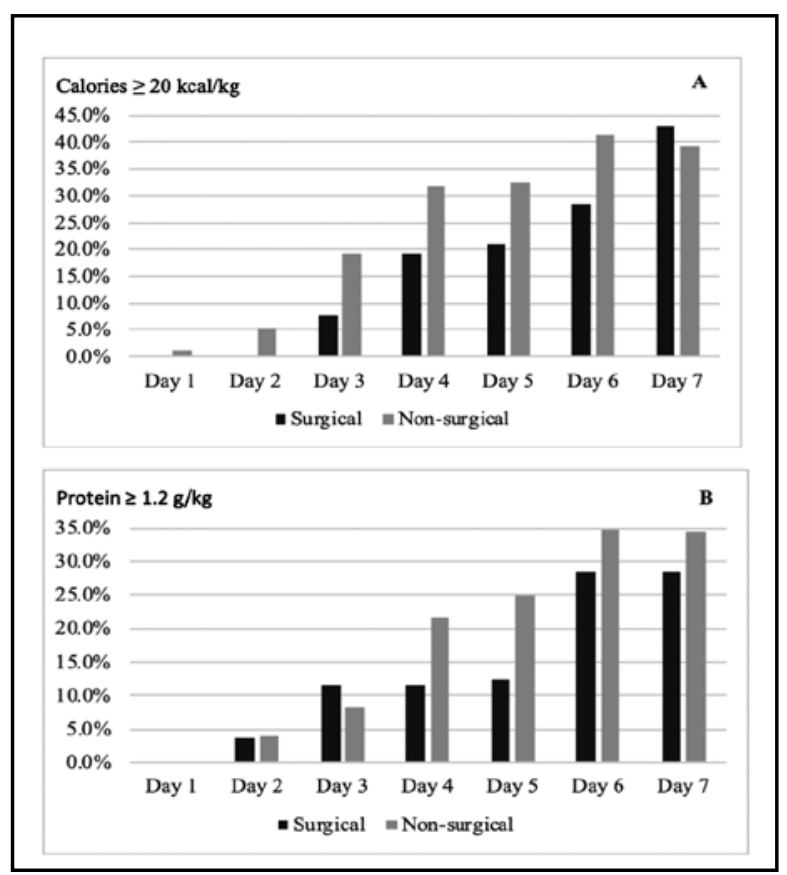

Figure 2: Percentage of patients with a calorie delivery $\geq 20 \mathrm{kcal} / \mathrm{kg} /$ day $(\mathrm{A})$ and protein delivery $\geq 1.2 \mathrm{~g} / \mathrm{kg} /$ day (B) during the first week after admission to the intensive care unit, according to the day and surgical status. There were no statistically significant differences between the surgical and non-surgical patients. Chi square test.

Table 3. Hospital outcomes according to surgical status.

\begin{tabular}{|lcccc|}
\hline Hospital outcomes & $\begin{array}{c}\text { Total } \\
\mathbf{n = 1 0 3}\end{array}$ & $\begin{array}{c}\text { Surgical } \\
\mathbf{n = 2 7}\end{array}$ & $\begin{array}{c}\text { Non-surgical } \\
\mathbf{n = 7 6}\end{array}$ & P-value \\
\hline Length of ICU stay (days), & 12.0 & 11.0 & 12 & $0.964^{\ddagger}$ \\
median (P25-P75) & $(8.0-19.0)$ & $(8.0-21.0)$ & $(8.0-18.5)$ & \\
Length of hospital stay (days), & 25.0 & 28.0 & 24.0 & $0.333^{\ddagger}$ \\
median (P25-P75) & $(13.0-43.5)$ & $(15.0-39.0)$ & $(11.8-45.2)$ & $0.010^{*}$ \\
Home discharge, $\mathrm{n}(\%)$ & $46(44.7)$ & $18(66.7)$ & $28(36.8)$ & $0.037^{*}$ \\
Death, n (\%) & $51(50.5)$ & $9(33.3)$ & $42(55.3)$ & \\
\hline
\end{tabular}

${ }^{\ddagger}$ Mann-Whitney $\mathrm{U}$ test, ${ }^{*}$ Chi-square test.

Abbreviations: ICU, intensive care unit; P25-P75, 25th and 75th percentile values. 


\section{DISCUSSION}

Our study demonstrated that after ICU admission critically ill surgical patients started ENT later than other critically ill patients. During the first week after ICU admission, both groups of patients had a low delivery of calories and proteins, with calorie and protein delivery being significantly lower in surgical patients.

Due to ethical considerations, there are no clinical trials on the effect of fasting on the outcomes of critically ill patients, because nutrient intake is essential for long-term survival $^{3}$. However, it is known that critical illness can lead to impaired immune function, with a persistent acute-phase response, systemic inflammation, and intense protein catabolism $^{20}$. Critically ill patients have high proteolysis and may lose up to $1 \mathrm{~kg}$ of muscle mass per day, leading to loss of muscle strength, which may be associated with the acquired weakness in the ICU ${ }^{21}$ and which may persist for up to five years ${ }^{22,23}$.

For more than a decade, guidelines and consensus statements of nutritional therapy societies have consistently recommended that in critically ill patients, who have no contraindication to enteral nutrition, ENT should be introduced between 24 and 48 hours after admission to the ICU 1,3,24,25. The ENT plan should be progressively reassessed to meet the nutritional needs of the patient during the first week of hospitalization. In our study, $67 \%$ of patients remained without any type of nutritional therapy on the second day (48 hours after admission), and $68 \%$ of patients started ENT on the fourth day after admission. This postponement was more frequent in surgical patients. Several studies have shown that there is a delay in starting ENT after patients

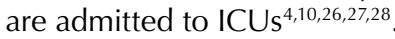

In addition to the late starting time of nutritional therapy, the maximum quantity of calories delivered in our study was $14 \mathrm{kcal} / \mathrm{kg} /$ day, on the last day of the week. Protein supply was also below the international recommendations ${ }^{1,2,3}$, with a maximum supply of $0.8 \mathrm{~g} / \mathrm{kg} / \mathrm{day}$ by the end of the first week. This low delivery of calories and proteins in both groups during the first week of ICU hospitalization can be considered a form of underfeeding ${ }^{3}$.

Inadequate calorie and protein intake during hospitalization, especially while in intensive care, may lead to an increased incidence of infectious complications, longer duration of mechanical ventilation, longer hospital stay, an increased risk of death, in addition to loss of muscle mass, poorer nutritional status, and poorer short-term functional recovery $y^{3,10,12,26,29,30,31}$.

Calorie underfeeding has been associated with less favorable outcomes in several reports $3,9,26,29$, yet this positive association depends on how the calorie target is calculated (predictive equations or indirect calorimetry) and the outcomes evaluated. Arabi et $\mathrm{al}^{15}$, studied permissive underfeeding (40-60\% of calculated caloric requirements) using predictive equations to calculate calorie target, and did not find differences in ICU and hospital mortality in comparison with a standard enteral feeding group (70-100\%).
According to the latest ESPEN guidelines ${ }^{3}$ hypocaloric diets (up to $70 \%$ estimated energy) should be used over isocaloric diets $(70 \%$ or greater) in the early phase of acute illness when predictive equations are used to calculate the energy needs, since these equations can overestimate the energy requirements. Also, in a underfeeding condition, Petros et $\mathrm{al}^{14}$, found lower insulin demand and lower gastrointestinal intolerance in ICU patients fed with a hypocaloric enteral diet during the first seven days of ICU hospitalization $(50 \%$ of daily energy expenditure), however this group had more nosocomial infections and no differences in ICU and hospital mortality were observed.

The negative effect of hypocaloric delivery in critically ill patients likely depends on the disease phase and can be observed if the underfeeding is maintained for more than seven days. In fact, Compher et al demonstrated lower incidence of death at the twelfth day in patients receiving high calorie amounts in comparison to those receiving low calorie amounts, but did not observe these differences when groups were compared at the fourth day of ICU stay ${ }^{11}$.

Timing of protein intake may also have an impact on clinical outcomes. Low protein intake $(<0.8 \mathrm{~g} / \mathrm{kg} /$ day $)$ before day 3 and higher protein intake (>0.8 g/ $\mathrm{kg} /$ day) after day 3 have both been associated with lower mortality in critically ill patients on prolonged mechanical ventilation ${ }^{32}$. Lower mortality has also been linked to a high protein intake level $(\geq 1.2 \mathrm{~g} / \mathrm{kg})$ at day 4 in non-septic mechanically ventilated ICU patients ${ }^{9}$. Unfortunately, these analyses could not be performed in our study due to the overall low nutrient delivery.

Furthermore, critically ill patients with a high nutritional risk (NUTRIC Score classified $>5$ ) might be more sensitive to nutritional therapy, presenting with lower mortality after higher nutritional intake. Well-nourished patients or those with mild nutritional risk did not present the same results, and no association between nutrient supply and clinical outcomes was identified ${ }^{33}$.

Therefore, the relationship between ENT and outcomes depends on a series of factors including, the delivery of calories and proteins, the method to target energy prescription, the period of hospital stay in which enteral nutrition is evaluated, the timing of nutrient intake, the outcomes studied, and the nutritional status of the patients.

Critically ill surgical patients on ENT received less energy and protein than other critically ill patients, and there are relatively few studies that assess the long-term impact of low nutrient delivery in critically ill surgical patients. In our study, surgical patients started ENT 24 hours (1 day) later than non-surgical patients, their median calorie delivery was 3.2 times lower, and median protein intake was 4 times lower, than that of non-surgical patients. In our study, the frequency of gastrointestinal complications did not differ between groups, and therefore, the lower calorie and protein delivery in surgical patients cannot be ascribe to ENT intolerance. These differences in delivery may be related to the "surgeons' fear" of anastomotic dehiscence when nutritional therapy is started early. However, these 
differences were not observed in a metanalysis of 15 studies involving patients undergoing resection gastrointestinal surgery, in which patients were randomized to start enteral feeding within 24 hours or later $(\mathrm{OR}=0.75 ; \mathrm{Cl} 95 \% 0.39-1.4)^{34}$.

Similar to our results, previous studies have shown that nutritional therapy is often initiated later in surgical patients and that they receive less calories and nutrients compared to non-surgical patients ${ }^{16,28,35}$. In a study of 2,072 critically ill surgical patients and 3,425 non-surgical patients, Drover et $\mathrm{a}^{16}$ found that surgical patients were significantly less likely to receive ENT and started ENT 21 hours later. Declercq et $\mathrm{al}^{35}$ confirmed that surgical patients received lower calorie $(43.2 \pm 36.3 \%$ vs $61.4 \pm 34.4 \%)$ and protein content $(38.1 \pm$ $32.8 \%$ vs. $56.8 \pm 32.7 \%$ ) than non-surgical patients. A low ENT leads to an accumulation of nutrient deficits, which can negatively affect clinical outcomes ${ }^{36}$.

In critically ill surgical patients, both caloric and protein nutritional inadequacy, has been associated with worse clinical outcomes, including longer ICU and hospital stays, longer duration of mechanical ventilation, greater risk of complications during hospitalization, and a lower home discharge rate compared to non-surgical critically ill patients $37,38,39$. Critically ill surgical patients, in addition to having increased metabolic demands, require calories and nutrients for wound healing. They also undergo more procedures and, therefore, are more likely to experience the consequences of the body's response to trauma and increased protein catabolism. These patients require higher amounts of protein to ensure an optimal nitrogen balance ${ }^{40}$.

Regarding the outcomes of our study, although the surgical patients were kept fasting for longer and had lower nutrient delivery in terms of calories and protein, they had lower mortality and higher home discharge. Drover et al ${ }^{16}$ also found better outcomes in critically ill surgical patients even though nutritional therapy was started later in these patients and they received less calories and protein. Some participant characteristics may have contributed to the difference between our outcomes; surgical patients were younger overall, had a lower nutritional risk, and none had severe malnutrition. Based on these characteristics, the surgical patients were likely to benefit less from full nutritional support ${ }^{33}$. However, as the infusion of calories and proteins was low for all patients, surgical patients may have been better protected against poor outcomes given their better previous nutritional status, and thus, the impact of a poor ENT delivery may have been less pronounced in this group.

Additionally, the length of ICU and hospital stays were high in both groups, which may have been influenced by the low delivery of nutrients in the first week of hospitalization. However, these are only hypotheses, as the sample size of the current study, and the number of surgical patients included, limited our statistical power and prevented us from performing a stratified analysis on the association of energy and protein inadequacy with the clinical outcomes of mortality and length of ICU stay. Futures studies should be performed to explore these associations in critically ill patients who have undergone surgery.

There were some limitations in the present study. As cited above, the limited sample size and low adequacy of proteins and calories did not allow us to do subgroup analyses according to whether participants received the minimum adequate nutrients. Hence, the outcomes cannot be related to the adequacy of calorie and protein intake. In addition, due to reasons we are unable to explain, ENT was prescribed, but not introduced for some patients, making it impossible to determine all the factors that might negatively affect the provision of this interdisciplinary nutrition therapy service.

\section{CONCLUSION}

This study found that, in critically ill patients, ENT was started late, and that calorie and protein intake via ENT was low. It took significantly longer to start ENT among surgical patients, and their calorie and protein intake was significantly lower than that of non-surgical patients, but that at the end of the first week of hospitalization, calorie and protein intake did not differ between the groups. Although presented with poorer nutritional adequacy, the surgical patient group had lower mortality and a higher rate of hospital discharge, which may be related to their younger age and better initial nutritional status compared to nonsurgical patients. Benefits of short-term underfeeding cannot be ruled out as an explanation for these differences, but it is unlikely since overall nutrient intake was dramatically low for comparison.

Further studies are needed to determine the role of different levels of calorie-protein intake in critically ill surgical patients, and the long-term impact of their nutritional management. The results of this study reflect the difficulty in providing nutritional therapy to critically ill patients, especially surgical patients.

\section{REFERENCES}

1. McClave SA, Taylor BE, Martindale RG, Warren MM, Johnson DR, Braunschweig $C$, et al. Guidelines for the provision and assessment of nutrition support therapy in the adult critically ill patient: Society of Critical Care Medicine (SCCM) and American Society for Parenteral and Enteral Nutrition (ASPEN). I Parenter Enteral Nutr. 2016; 40: 159-211.

2. Heyland DK, Dhaliwal R, Day A, Jain M, Drover J. Validation of the Canadian clinical practice guidelines for nutrition support in mechanically ventilated, critically ill adult patients: Results of a prospective observational study. Crit Care Med 2004; 32: 2260-2266.

3. Singer $P, B$ laser AR, Berger MM, Alhazzani W, Calder PC, Casaer MP, et al. ESPEN guideline on clinical nutrition in the intensive care unit. Clin Nutr. 2019; 38: 48-79.

4. Cahill NE, Dhaliwal R, Day AG, Jiang X, Heyland DK. Nutrition therapy in the critical care setting: What is "best achievable" practice? An international multicenter observational study. Crit Care Med. 2010; 38: 395-401.

5. Heyland DK, Dhaliwal $R$, Wang M, Day AG. The prevalence of iatrogenic underfeeding in the nutritionally 
'at-risk' critically ill patient: Results of an international, multicenter, prospective study. Clin Nutr. 2015; 34: 659-666.

6. Stewart $M L$, Biddle M, Thomas T. Evaluation of current feeding practices in the critically ill: A retrospective chart review. Intensive Crit Care Nurs. 2017; 38: 24-30.

7. Mitchell A, Clemente R, Downer C, Greer F, Allan K, Collinson $A$, et al. Protein provision in critically ill adults requiring enteral nutrition: Are guidelines being met? Nutr Clin Pract. 2019; 34: 23-130.

8. Hoffer LJ, Bistrian BR. Nutrition in critical illness: A current conundrum. F1000Res. 2016; 5: 2531.

9. Weijs PJ, Looijaard GT, Beishuizen A, Girbes AR, Oudemans-van Straaten HM. Early high protein intake is associated with low mortality and energy overfeeding with high mortality in non-septic mechanically ventilated critically ill patients. Crit Care. 2014; 18: 701-713.

10. Nicolo M, Heyland DK, Chittams J, Sammarco T, Compher C. Clinical outcomes related to protein delivery in a critically ill population: A multicenter, multinational observation study. J Parenter Enteral Nutr. 2016; 40: 45-51.

11. Compher C, Chittams J, Sammarco T, Nicolau H, Heyland DK. Greater protein and energy intake may be associated with improved mortality in higher risk critically ill patients: A multicenter, multinational observational study. Crit Care Med. 2017; 45: 156-163.

12. Fetterplace K, Deane AM, Tierney A, Praia LJ, Presneill J, Rechnitzer $T$, et al. Targeted full energy and protein delivery in critically ill patients: A pilot randomized controlled trial (FEED Trial). J Parenter Enteral Nutr. 2018; 42: 1252-1262.

13. Looijaard WGPM, Denneman N, Broens B, Girbes ARJ, Weijs PJM, Oudemans-van Straaten HM, et al. Achieving protein targets without energy overfeeding in critically ill patients: A prospective feasibility study. Clin Nutr. 2019; 38: 2623-2631.

14. Petros S, Horbach M, Seidel F, Weidhase L. Hypocaloric vs normocaloric nutrition in critically ill patients: $A$ prospective randomized pilot trial. I Parenter Enteral Nutr. 2016; 40: 242-249.

15. Arabi YM, Aldawood AS, Samir H, Al-Dorzi HM, Tamim $H H$, Jones $G$, et al. Permissive underfeeding or standard enteral feeding in critically ill adults. New Engl J Med. 2015; 372: 2398-2408.

16. Drover JW, Cahill NE, Kutsogiannis J, Pagliarello G, Wischmeyer $P$, Wang $M$, et al. Nutrition therapy for the critically ill surgical patient: We need to do better. I Parenter Enteral Nutr. 2010; 34: 644-652.

17. Yeh DD, Ortiz LA, Lee JM, Chan J, Mckenzie K, Young B, et al. PEP up (Enhanced Protein-Energy Provision via the Enteral Route Feeding Protocol) in surgical patients: A multicenter pilot randomized controlled trial. J Parenter Enteral Nutr. 2020; 44: 197-204.

18. Rahman A, Hasan RM, Agarwala R, Martin C, Day AG, Heyland DK. Identifying critically-ill patients who will benefit most from nutritional therapy: Further validation of the "modified NUTRIC" nutritional risk assessment tool. Clin Nutr. 2016; 35: 158-162.

19. Detsky AS, MCLaughlin JR, Baker JP, Johnston N, Whittaker S, Mendelson RA, et al. What is subjective global assessment of nutritional status? J Parenter Enteral Nutr. 1987; 11: 8-13.
20. Moore FA, Phillips SM, McClain CJ, Patel JJ, Martindale RG. Nutrition support for persistent inflammation, immunosuppression, and catabolism syndrome. Nutr Clin Pract. 2017; 32: 121S-127S.

21. Puthucheary ZA, Rawal J, McPhail M, Connoly B, Ratnayake $G$, Chan $P$, et al. Acute skeletal muscle wasting in critical illness. JAMA. 2013; 310: 1591-1600.

22. Herridge MS, Tansey CM, Matté A, Tomlinson G, DiazGranados N, Cooper A, et al. Functional disability 5 years after acute respiratory distress syndrome. N Engl J Med. 2011; 364: 1293-1304.

23. Iwashyna TI, Ely EW, Smith DM, Langa KM. Long-term cognitive impairment and functional disability among survivors of severe sepsis. JAMA. 2010; 304: 1787-1794.

24. Reintam BA, Starkopf J, Alhazzani W, Berger MM, Casaer $M P$, Deane $A M$, et al. Early enteral nutrition in critically ill patients: ESCIM clinical practice guidelines. Intensive Care Med 2017; 43: 380-398.

25. Heyland DK, Dhaliwal R, Drover JW, Gramlich L, Dodek P. Canadian clinical practice guidelines for nutrition support in mechanically ventilated, critically ill adult patients. I Parenter Enteral Nutr. 2003; 27: 355-373.

26. Alberda C, Gramlich L, Jones N, Jeejeebhoy K, Day AG, Dhaliwal $R$, et al. The relationship between nutritional intake and clinical outcomes in critically ill patients: Results of an international multicenter observational study. Intensive Care Med. 2009; 35: 1728-1737.

27. Binnekade JM, Tepaske R, Bruynzeel P, Mathus-Vliegen $E M$, de Hann RJ. Daily enteral feeding practice on the ICU: Attainment of goals and interfering factors. Crit Care. 2005; 9: R218-R225.

28. Heyland DK, Schroter-Noppe D, Drover JW, Jain M, Keefe $G$, Dhaliwal R, et al. Nutrition support in the critical care setting: Current practice in Canadian ICUs-opportunities for improvement? I Parenter Enteral Nutr. 2003; 27: 74-83.

29. Zusman O, Theilla M, Cohen J, Kagan I, Bendavid I, Singer P. Resting energy expenditure, calorie and protein consumption in critically ill patients: A retrospective cohort study. Crit Care 2016; 20: 367-378.

30. Heyland DK, Stephens KE, Day AG, McClave SA. The success of enteral nutrition and ICU-acquired infections: A multicenter observational study. Clin Nutr. 2011; 30: 148-155.

31. Wei X, Day AG, Ouellette-Kuntz H, Heyland DK. The association between nutritional adequacy and long-term outcomes in critically ill patients requiring prolonged mechanical ventilation: A multicenter cohort study. Crit Care Med. 2015; 43: 1569-1579.

32. Koekkoek WAC, Setten CH, Olthof LE, Kars JCNH, Van Zanten ARH. Timing of PROTein INtake and clinical outcomes of adult critically ill patients on prolonged mechanical VENTilation: The PROTINVENT retrospective study. Clin Nutr. 2018; 38: 883-890.

33. Compher C, Chittams J, Sammarco T, Higashibeppu N, Higashiguchi T, Heyland DK. Greater nutrient intake is associated with lower mortality in Western and Eastern critically ill patients with low BMI: A multicenter, multinational observational study. J Parenter Enteral Nutr. 2019; 43: 63-69.

34. Osland E, Yunus RM, Khan S, Memon MA. Early versus traditional postoperative feeding in patients undergoing resectional gastrointestinal surgery: A meta-analysis. J Parenter Enteral Nutr 2011; 35: 473-487. 
35. Declercq B, Deane AM, Wang M, Chapman MJ, Heyland DK. Enhanced Protein-Energy Provision via the Enteral Route Feeding (PEP up) protocol in critically ill surgical patients: A multicenter prospective evaluation. Anaesth Intensive Care. 2016; 44: 93-98.

36. Villet S, Chiolero RL, Bollmann MD, Revelly JP, Cayeux RNMC, Delarue J, et al. Negative impact of hypocaloric feeding and energy balance on clinical outcome in ICU patients. Clin Nutr. 2005; 24: 502-509.

37. Yeh DD, Fuentes E, Quraishi SA, Cropano C, Kaafarani $H$, Lee J, et al. Adequate nutrition may get you home: Effect of caloric/protein deficits on the discharge destination of critically ill surgical patients. J Parenter Enteral Nutr. 2016; 40: 37-44.
38. Yeh DD, Peev MP, Quraishi SA, Osler P, Chang Y, Rando $E G$, et al. Clinical outcomes of inadequate calorie delivery and protein deficit in surgical intensive care patients. Am J Crit Care. 2016; 25: 318-326.

39. Yeh DD, Ortiz-Reyes LA, Quraishi SA, Chokengarmwong $N$, Avery L, Kaafarani HMA, et al. Early nutritional inadequacy is associated with psoas muscle deterioration and worse clinical outcomes in critically ill surgical patients. J Crit Care. 2018; 45: 7-13.

40. Dickerson RD, Pitts SL, Maish G, Schroeppel TJ, Magnotti $L$ J, Croce MA, et al. A reappraisal of nitrogen requirements for patients with critical illness and trauma. I Trauma Acute Care Surg. 2012; 73: 549-557. 